\title{
Efek perilaku mengunyah terhadap indeks massa tubuh
}

\author{
Rio Guntur Maharsi ${ }^{1}$, Kartika Indah Sari ${ }^{1}{ }^{*}$, Rosiliwati Wihardja ${ }^{1}$, Indrati ${ }^{1}$, \\ Nanan Nur'aeny ${ }^{2}$
}

\author{
${ }^{1}$ Departemen Oral Biologi, Fakultas Kedokteran Gigi Universitas Padjadjaran, Indonesia \\ ${ }^{2}$ Departemen Ilmu Penyakit Mulut, Fakultas Kedokteran Gigi Universitas Padjadjaran, Indonesia
}

*Korespondensi: kartika.sari@fkg,unpad.ac.id

\begin{abstract}
ABSTRAK
Pendahuluan: Perilaku mengunyah setiap orang memerlukan waktu mengunyah yang berbeda. Waktu mengunyah tersebut menggambarkan seberapa cepat seseorang untuk mengunyah. Semakin cepat mengunyah maka orang tersebut memiliki kecenderungan untuk mengalami kelebihan berat badan. Penelitian ini bertujuan untuk mengetahui hubungan antara perilaku mengunyah (kecepatan mengunyah) terhadap berat badan. Metode: Empat puluh delapan orang mahasiswa Fakultas Kedokteran Gigi Universitas Padjadjaran terpilih untuk mengikuti penelitian ini. Setiap subjek mengikuti pengukuran tinggi badan dan berat badan. Subjek penelitian diminta melakukan puasa 8 jam sebelumnya, tes makan dilakukan pada pagi hari pukul dengan porsi makanan seberat 430 gram. Pengukuran waktu makan dilakukan dengan menggunakan stopwatch. Data dianalisis dengan menggunakan uji korelasi rank Spearman. Hasil: terdapat hubungan yang bermakna (p\&lt;0,05; $p=0,031)$ dengan koefisien korelasi positif $(0,311)$ antara kecepatan pengunyahan dengan indeks massa tubuh. Simpulan: Korelasi kecepatan pengunyahan berbanding lurus dengan Indeks Massa Tubuh. Semakin tinggi kecepatan mengunyah maka semakin tinggi kecenderungan seseorang memiliki IMT di atas rata-rata.
\end{abstract}

Kata kunci: Kecepatan pengunyahan, Indeks Massa Tubuh, obesitas

\section{Effects of chewing behaviour on body mass index}

\begin{abstract}
Introduction: Individual chewing behaviour requires a different chewing time. The chewing time illustrates how fast someone is chewing. The faster the chews, the higher this person tends to be overweight. This study was aimed to determine the relationship between chewing behaviour (chewing speed) on body weight. Methods: Forty-eight students of the Faculty of Dentistry Universitas Padjadjaran were selected to be taken part in this study. Each subject's height and weight were measured. The study subjects were asked to fast 8 hours earlier; the feeding test was carried out in the morning with a portion of food weighed 430 grams. Mealtime measurement was performed using a stopwatch. Data were analysed using Spearman's rank correlation test. Results: There was a significant correlation ( $p<0.05 ; p=0.031$ ) with a positive correlation coefficient (0.311) between chewing speed and body mass index. Conclusion: The correlation between the speed of mastication is directly proportional to the Body Mass Index (BMI). The higher the chewing speed, the higher the tendency for someone to have above the average BMI.
\end{abstract}

Keywords: Chewing speed, Body Mass Index, obesity 


\section{PENDAHULUAN}

Proses mengunyah termasuk ke dalam mekanisme sistem pencernaan yang terjadi di dalam mulut dengan bantuan organ-organ seperti lidah, gigi, dan kelenjar saliva. Prinsip fungsi pengunyahan adalah menghancurkan partikel makanan menjadi butiran yang lebih halus sehingga siap untuk ditelan. ${ }^{1}$ Fungsi pengunyahan dapat ditinjau berdasarkan parameter yang biasa disebut sebagai masticatory performance. Parameter yang dapat dinilai dari masticatory performance terdiri dari eating rate (kecepatan pengunyahan), bite size (ukuran gigitan), number of bites (jumlah gigitan), meal duration (durasi makan), dan penurunan eating rate (deceleration rate). ${ }^{2}$

Indeks Massa Tubuh (IMT) merupakan salah satu indikator yang sering digunakan untuk menentukan status gizi seseorang. Hasil perhitungan IMT dapat diklasifikasikan ke dalam empat kelompok, yaitu underweight, normal, overweight, dan obesitas. Penelitian mengenai IMT sering dikaitkan dengan risiko penyakit sistemik seperti diabetes mellitus, gangguan kardiovaskular, dan lainnya, namun masih sangat jarang ditemukan penelitian yang mengaitkan perilaku mengunyah dengan Indeks Massa Tubuh. ${ }^{3}$ Suatu penelitian di Jepang menunjukkan bahwa individu dengan nilai IMT $\geq 30,0 \mathrm{~kg} / \mathrm{m} 2$ mengalami peningkatan risiko mortalitas (kematian) akibat penyakit jantung koroner. $^{3,4}$ Penelitian lain mengungkapkan bahwa kecepatan pengunyahan memberikan dampak yang signifikan terhadap status berat badan seseorang.

Perilaku slow eating diyakini dapat meningkatkan rasa kenyang dan memberikan rasa nyaman dalam waktu lama dibandingkan dengan perilaku fast eating. ${ }^{5}$ Hal ini diduga berkaitan dengan kerja hormon dan peptida yang menekan nafsu makan (anoreksigenik) seperti glucagon-like peptide-1, peptida YY, dan kolesistokinin, dan hormon yang merangsang nafsu makan (oreksigenik) seperti ghrelin. ${ }^{6,7}$

Penelitian ini bertujuan untuk mengetahui hubungan antara kecepatan pengunyahan sebagai salah satu parameter dalam masticatory performance dengan Indeks Massa Tubuh (IMT) pada mahasiswa yang dapat digolongkan ke dalam kelompok dewasa muda. Hasil penelitian ini dapat dijadikan sebagai sumber informasi bagi tenaga kesehatan dan masyarakat terkait pentingnya memperhatikan perilaku mengunyah sebagai alternatif untuk menjaga berat badan.

\section{METODE}

Penelitian ini merupakan penelitian korelasional dengan desain penelitian cross sectional. Sampel yang digunakan dalam penelitian ini sebanyak 48 orang mahasiswa FKG Unpad angkatan 2017. Mahasiswa FKG Unpad angkatan 2017 dipilih karena dapat mewakili kelompok dewasa muda (usia 18-25 tahun).

Pemilihan sampel menggunakan metode purposive sampling, yaitu metode pengambilan sampel berdasarkan pada kriteria inklusi, meliputi kondisi jaringan keras (gigi, tulang alveolar) dan jaringan lunak (gingiva, ligamen periodontal, mukosa mulut, lidah) rongga mulut sehat, tidak terdapat gejala periodontitis kronis seperti perdarahan, pembengkakan dan/atau resesi pada gingiva, oklusi gigi kelas I Angle, dan jumlah gigi permanen minimal 28. Kriteria eksklusi sampel penelitian antara lain sedang menjalani program diet, memiliki riwayat penyakit sistemik, gangguan eating disorder (misal anoreksia), sedang menjalani perawatan ortodonti dan/atau gigi tiruan, memiliki restriksi dan alergi terhadap suatu makanan, serta mengonsumsi obat-obatan yang dapat memengaruhi kebiasaan makanan.

Penelitian ini dilakukan di Laboratorium Oral Biologi Fakultas Kedokteran Gigi Universitas Padjadjaran Kampus Jatinangor pada Maret 2018 dan sudah memperoleh izin etik dari Komite Etik Fakultas Kedokteran Universitas Padjadjaran (No. 151/UN6.KEP/EC/2018). Setiap sampel diberikan pengarahan terlebih dahulu dan diminta mengisi informed consent sebagai tanda bersedia mengikuti penelitian hingga selesai.

Penelitian dilakukan pada pagi hari pukul 09.00 dan subjek sudah berpuasa 8 jam sebelumnya. Pengukuran tinggi badan dan berat badan setiap subjek dilakukan untuk mengetahui Indeks Massa Tubuh. Porsi makanan yang diberikan pada subjek yaitu nasi, telur mata sapi, sayur tauge dan tahu, sambal, serta air mineral dengan massa yang sama bagi setiap subjek sebesar 430 gram.

Subjek diinstruksikan untuk menghabiskan makanan tanpa perlakuan khusus. Waktu yang dibutuhkan setiap sampel untuk makan didata untuk mengetahui kecepatan pengunyahan. Kecepatan pengunyahan dihitung menggunakan rumus massa/ Kecepatan Pengunyahan = Massa makanan yang dikonsumsi waktu pengunyahan, sedangkan indeks 
Massa Tubuh (IMT) dihitung dengan menggunakan rumus: Indeks Massa Tubuh $=$ Berat badan/tinggi badan. $^{2}$ Nilai IMT diukur sebelum melakukan tes makan. Pengelompokan IMT pada penelitian ini mengacu pada klasifikasi IMT untuk regio Asia Pasifik. ${ }^{2}$ Uji analisis statistika menggunakan IBM SPSS Statistics 22. Normalitas data diuji menggunakan Shapiro-Wilk test, dengan confidence interval sebesar 95\%. Uji korelasi metode rank Spearman digunakan untuk menganalisis korelasi antara kecepatan pengunyahan dan Indeks Massa Tubuh.

\section{HASIL}

Penelitian ini menggunakan sampel sebanyak 48 orang. Karakteristik subjek penelitian terdiri dari distribusi gender, rerata tinggi badan, dan rerata berat badan.yang disajikan dalam tabel 1 .

Tabel 1. Karakteristik subjek penelitian

\begin{tabular}{lc}
\hline \multicolumn{1}{c}{ Karakteristik Subjek } & N \\
\hline Jenis Kelamin & 11 \\
Pria & 37 \\
Wanita & \\
Berat Badan (kg) & 57,04 \\
Rata-Rata & 13,81 \\
Standar Deviasi & \\
Tinggi Badan (cm) & 158,13 \\
Rata-Rata & 7,53 \\
Standar Deviasi & \\
\hline
\end{tabular}

Hasil perhitungan waktu makan, massa makanan, dan kecepatan pengunyahan subjek penelitian disajikan dalam tabel 2 .

Tabel 2. Hasil tes makan pada subjek penelitian

\begin{tabular}{lc}
\hline \multicolumn{1}{c}{ Karakteristik subjek } & N \\
\hline Waktu makan (menit) & 11 \\
Rerata & 37 \\
Standar deviasi & \\
Massa makanan (gram) & 57,04 \\
Rata-rata & 13,81 \\
Standar deviasi & \\
Kecepatan pengunyahan(gr/menit) & 158,13 \\
Rata-rata & 7,53 \\
Standar deviasi & \\
\hline
\end{tabular}

Tabel 3. Indeks massa tubuh pada subjek penelitian

\begin{tabular}{lc}
\multicolumn{1}{c}{ Subjek penelitian } & N \\
\hline IMT $(\mathrm{kg} / \mathrm{m} 2)$ & 22,76 \\
Rerata & 4,83 \\
Standar Deviasi & \\
Status Gizi & 5 \\
Underweight $(<18,5 \mathrm{~kg} / \mathrm{m} 2)$ & 27 \\
Normal $(18,5-22,9 \mathrm{~kg} / \mathrm{m} 2)$ & 6 \\
Overweight $(23,0-24,9 \mathrm{~kg} / \mathrm{m} 2)$ & 10 \\
Obesitas $(\geq 25,0 \mathrm{~kg} / \mathrm{m} 2)$ & 7,53 \\
Standar Deviasi & \\
\hline
\end{tabular}

Tabel 4. Hasil uji korelasi rank spearman

\begin{tabular}{llll}
\hline Variabel & $\begin{array}{l}\text { Koefisien } \\
\text { Korelasi }\end{array}$ & $\begin{array}{l}\text { Hubungan } \\
(\mathbf{r})\end{array}$ & $\begin{array}{l}\text { p-value } \\
(\boldsymbol{\alpha})\end{array}$ \\
\hline $\begin{array}{l}\text { Kecepatan pengunyahan } \\
\text { terhadap indeks massa } \\
\text { tubuh }\end{array}$ & 0,311 & 0,031 & 0,031 \\
\hline
\end{tabular}

Bahwa terdapat hubungan yang berbanding lurus antara kecepatan pengunyahan dengan Indeks Massa Tubuh. Semakin tinggi kecepatan mengunyah akan menyebabkan semakin tinggi Indeks Massa Tubuh. Nilai korelasi sebesar 0,031 menunjukkan bahwa hubungan kecepatan mengunyah dengan Indeks Massa Tubuh adalah sebesar 3\% atau sangat rendah. Nilai p-value adalah 0,031 . Nilai p-value berada di bawah $0,05(\alpha<0,05)$ yang berarti pengaruh antara kecepatan pengunyahan terhadap Indeks Massa Tubuh (IMT) dianggap bermakna.

\section{PEMBAHASAN}

Penelitian ini menghasilkan nilai rata-rata kecepatan pengunyahan subjek penelitian sebesar 47,21 gram/ menit. Nilai ini termasuk lebih rendah dibandingkan dengan beberapa penelitian yang telah dilakukan sebelumnya. Studi yang dilakukan sebelumnya memperoleh angka rata-rata kecepatan pengunyahan 66 gram/menit dengan massa makanan yang hampir sama dengan massa makanan untuk penelitian ini yaitu 400 gram. ${ }^{1}$

Penelitian yang dilakukan kepada responden mahasiswa Universitas Rhode Island menghasilkan rata-rata waktu mengunyah 8,4 menit dengan ratarata massa makanan yang dikonsumsi 488,2 gram. Nilai-nilai di atas apabila dikonversi, maka akan diperoleh nilai rata-rata kecepatan pengunyahan sebesar 58,12 gram/menit. Perbedaan kecepatan mengunyah di atas kemungkinan disebabkan oleh 
jenis dan tekstur sampel makanan yang digunakan. Penelitian di Eropa biasanya menggunakan sampel makanan pokok di negara tersebut, misalnya pasta, sereal dan lainnya, sementara sampel makanan yang biasa digunakan pada penelitian di Asia adalah nasi dengan lauk yang teksturnya lebih padat. ${ }^{6}$ Tekstur makanan merupakan salah satu faktor eksternal yang dapat memengaruhi masticatory performance.,

Faktor sosial juga memungkinkan adanya perbedaan rata-rata kecepatan mengunyah. Penelitian di Amerika Serikat menunjukkan bahwa orang yang termasuk kelompok overweight dan/atau obesitas dapat mengonsumsi makanan lebih sedikit dibandingkan dengan kelompok normal karena kekhawatiran terhadap berat badannya. Mereka juga cenderung mengunyah secara perlahan untuk mengurangi porsi makan. Kebiasaan mengunyah tersebut dapat memberikan sugesti terhadap kelompok obesitas tersebut untuk mengunyah secara lambat meskipun sampel makanan yang digunakan tidak sama baik jenis maupun tekstur dengan sampel makanan yang biasa digunakan. ${ }^{6}$

Hasil uji analitik korelasional data penelitian ini menyatakan bahwa kecepatan pengunyahan memberikan hubungan yang berbanding lurus dengan IMT. Semakin cepat seseorang mengunyah maka semakin tinggi kemungkinan orang tersebut memiliki IMT yang tinggi. Hasil ini sejalan dengan penelitian yang dilakukan sebelumnya, yaitu penelitian di Selandia Baru dengan responden wanita berusia 40-50 tahun menyatakan bahwa kebiasaan mengunyah dengan cepat dapat meningkatkan IMT sebesar $3,1 \%{ }^{9}$

Kecepatan mengunyah yang bervariasi memiliki dampak yang berbeda-beda. Perilaku fast eating dapat memicu faktor risiko berupa peningkatan asupan energi yang berlebihan, obesitas, dan penyakit metabolisme lainnya. Perilaku slow eating lebih direkomendasikan para peneliti untuk menghindari asupan makanan berlebihan. Slow eating diyakini memungkinkan rasa kenyang muncul sebelum konsumsi makanan semakin berlebihan sehingga dapat membantu mengendalikan asupan energi. Risiko obesitas menjadi lebih mudah ditekan. ${ }^{10}$

Penelitian yang dilakukan adalah penelitian awal yang dapat menginisiasi penelitian selanjutnya terkait dengan kecepatan pengunyahan dan Indeks Massa Tubuh. Rerata kecepatan pengunyahan pada mahasiswa FKG Unpad adalah 47,21 gram/menit yang mewakili kecepatan rerata pada populasi peneliti. Pada penelitian diperoleh rerata IMT 22,76 $\mathrm{kg} / \mathrm{m} 2$ yang menunjukkan bahwa mayoritas populasi penelitian termasuk ke dalam kelompok normal. ${ }^{11}$

Uji statistik menyatakan bahwa terdapat korelasi positif antara kecepatan pengunyahan dengan Indeks Massa Tubuh namun bersifat lemah. Korelasi yang bersifat lemah itu kemungkinan karena jumlah proporsi kelompok IMT tergolong normal lebih mayoritas dibandingkan dengan klasifikasi lain. Penelitian lain diperlukan dengan proporsi kelompok yang relatif sama sehingga koefisien korelasinya lebih kuat.

\section{SIMPULAN}

Korelasi kecepatan pengunyahan berbanding lurus dengan Indeks Massa Tubuh. Semakin tinggi kecepatan mengunyah maka semakin tinggi kecenderungan seseorang memiliki IMT di atas ratarata.

\section{DAFTAR PUSTAKA}

1. Tortora GJ, Bryan H. Derrickson. Wiley J, Sons. Principles of anatomy and physiology Apr 11, 2008.

2. Almiron-Roig E, Tsiountsioura $\mathrm{M}$, Lewis HB, Wu J, Solis-Trapala I, Jebb SA. Large portion sizes increase bite size and eating rate in overweight women. Physiol Behav. 2015;139(Supplement C):297-302.

3. World Health Organization. Regional Office for the Western Pacific. The Asia-Pacific perspective: redefining obesity and its treatment. Sydney: Health Communications Australia. 2000.

4. Lim JU, Lee JH, Kim JS, Hwang Y Il, Kim T-H, Lim SY, et al. Comparison of World Health Organization and Asia-Pacific body mass index classifications in COPD patients. Int J Chron Obstruct Pulmon Dis. 2017;12:2465.

5. Martin CK, Anton SD, Walden H, Arnett C, Greenway FL, Williamson DA. Slower eating rate reduces the food intake of men, but not women: implications for behavioral weight control. Behav Res Ther 2007;45(10):2349-59.

6. Shah M, Copeland J, Dart L, Adams-Huet B, James A, Rhea D. Slower eating speed lowers energy intake in normal-weight but not overweight/obese subjects. J Acad Nutr Diet 2014;114(3):393-402. 
7. Kokkinos A, le Roux CW, Alexiadou K, Tentolouris N, Vincent RP, Kyriaki D, et al. Eating slowly increases the postprandial response of the anorexigenic gut hormones, peptide $\mathrm{YY}$ and glucagon-like peptide-1. J Clin Endocrinol Metab 2010;95(1):333-7.

8. Andrade AM, Kresge DL, Teixeira PJ, Baptista F, Melanson KJ. Does eating slowly influence appetite and energy intake when water intake is controlled? Int J Behav Nutr Phys Act 2012 Nov 21;9:135.

9. Do Nascimento TLH, Liberalesso NA, Balbinot
HJ, Neves HF. Association between underweight and overweight/obesity with oral health among independently living Brazilian elderly. Nutrition. 2013;29(1):152-7.

10. Leong SL, Madden C, Gray A, Waters D, Horwath C. Faster self-reported speed of eating is related to higher body mass index in a nationwide survey of middle-aged women. J Am Diet Assoc. 2011;111(8):1192-7.

11. McCrickerd K, Forde CG. Consistency of eating rate, oral processing behaviours and energy intake across meals. Nutrients. 2017;9(8):891. 